\title{
LAYANAN INFORMASI PADA RUMAH SAKIT MAMAMI KOTA KUPANG BERBASIS WEBS
}

\author{
Aprilia Ch Zampi, Edwin A. U. Malahina, Mardhalia Saitakela \\ ${ }^{2} 3$ Program Studi Teknik Informatika Strata Satu STIKOM Uyelindo Kupang \\ Jl. Perintis Kemerdekaan I - Kayu Putih - Kupang - NTT \\ Email: arlinzampi8939@gmail.com
}

\begin{abstract}
Kupang City is municipality city and East Nusa Tenggara Capital city at once. Its glowing population, from time to time, causing varied problems, as such, in creasing pollution, limitedness resources, infrastructures and economic growth, thus generate broad impact, without exception, public healt threatening. Mamami Hospital is a prevate ownership healty mean in Kupang city,runing public trasition healt service, by general practioner, medical specialis on tooth, child, midwife service,internal disease, surgical operation, ophthaltmologist, tediarticiant, public care healt reference. Mamami Hospital, estimated, faces to potential problems, first, of its ignorance healt care information by a large member of Kupang's population, and second, possesses no available and accurate data on its patiens recording on digital device. Personally to thanks every one, the owner especeally, who received me to practice my digital device application skill at Mamami Hospital, writer would like to contributed a public information for mamami hospital. Further information on method of this research, researcher uses discription, bibliography observation and interview. Based on above finding, writer apprently suggest Mamami Hospital's, agent to answer its need to cultivate in their relationsip with patients by public health information from digital device. This public information facilitate them to communicate each other on their need.
\end{abstract}

Keywords : Information, Public Service, Mamami Hospital in Kupang, Website.

\section{PENDAHULUAN}

Dengan pertumbuhan penduduk yang semakin meningkat dari waktu ke waktu membuat Kota Kupang menghadapi berbagai macam persoalan antara lain peningkatan polusi, keterbatasan sumber daya, keterbatasan sarana prasarana dan pertumbuhan ekonomi yang semakin tinggi yang berdampak pada masalah kesehatan. Salah satu instansi yang bergerak di bidang kesehatan Kota Kupang yaitu Rumah Sakit Mamami. Rumah Sakit Mamami yaitu satu dari sekian Rumah Sakit milik perorangan Kota Kupang yang berbentuk RSU dan tergolong ke dalam Rumah Sakit tipe D yang saat ini di pimpin oleh direktur Dr.Thimotius Tarra Behy. Berdasarkan surat keputusan Kepala Dinas Kesehatan Provinsi Nomor 233/442.A/VII/2008 tanggal 18 Juli 2008 status rumah sakit ibu dan anak menjadi Rumah Sakit Umum Mamami. Sehabis melakukan prosedur akreditasi Rumah Sakit seluruh Indonesia dengan proses akhirnya ditetapkan status Akreditasi Rumah Sakit. Rumah Sakit ini bertempat di R.W. Jl.Mongonsidi No.3, Kota Kupang NTT, Indonesia.

Rumah Sakit Mamami bersifat transisi dengan kemampuan memberi pelayanan kedokteran umum, Spesialis gigi, Spesialis anak, Spesialis kebidanan dan kandungan, Spesialis penyakit dalam, Spesialis bedah, Spesialis mata, dan juga menampung rujukan yang berasal dari puskesmas. Dari hasil wawancara yang telah dilakukan peneliti dengan direktur Rumah Sakit Mamami bahwa pelayanan informasi kesehatan disasarkan kepada masyarakat Kota Kupang. Masalah yang sedang di hadapi pada Rumah Sakit ini yaitu masyarakat belum mengetahui informasi pelayanan kesehatan yang ada pada Rumah Sakit Mamami dan belum terarsipnya data-data pasien secara digital dimana sampai saat ini 
data-data pasien tersebut masih tersimpan dalam rak-rak penyimpanan. Hal ini tentunya kurang efektif karena akan membutuhkan waktu yang lama dalam pencarian data tersebut, juga tidak menutup kemungkinan data-data tersebut dapat hilang. Saat ini, belum tersedia informasi layanan kesehatan yang disajikan secara terintegrasi dikarenakan kurangnya tenaga kerja dalam bidang IT di Rumah Sakit ini. Untuk mengatasi masalah tersebut maka perlu dibangun sebuah Aplikasi Layanan Informasi Pada Rumah Sakit Mamami. Dengan adanya aplikasi berbasis website yang akan dibangun ini, diharapkan masyarakat dapat mengetahui informasi-informasi pelayanan kesehatan dan dapat membantu tata kelolah administrasi pada Rumah Sakit Mamami sehingga pasien tidak menunggu terlalu lama. Setelah melakukan kajian terhadap beberapa Karya ilmiah, peneliti menemukan penelitian yang mempunyai judul serupa diantaranya, Sairlay 2016 melakukan penelitian dengan judul Website Pengukuran Tingkat Kepuasan Layanan pada Puskesmas Sikumana. Tujuan dari penelitian ini untuk menjadi bahan evaluasi bagi pihak Puskesmas untuk memperbaiki layanan pada Puskesmas Sikumana. Pengukuran tingkat kepuasan layanan menggunakan Metode Customer Statisfaction Index (CSI). Untuk data dan informasi yang berhasil dikumpulkan penulis adalah dengan membuat kuisioner dengan menggunakan Metode Skala Likert. Produk yang dihasilkan dari penelitian ini adalah terciptanya sebuah website yang membantu pihak Puskesmas Sikumana untuk mengukur tingkat kepuasan layanan. Adapun Messakh 2017, dengan judul Layanan Informasi Panduan Makanan Dan Minuman Diet Berdasarkan Golongan Darah Berbasis Mobile Android (Online). Tujuan dari penelitian ini adalah membuat sebuah layanan informasi panduan makanan dan minuman diet berdasarkan golongan darah manusia berbasis mobile android (Online). Penelitian ini akan menghasilkan sebuah aplikasi yang dapat membantu para pelaku diet untuk menghindari kekeliruan dalam menjalankan program diet yang dikelompokan berdasarkan golongan darah, serta dengan mudah mendapatkan informasi di mana dan kapan saja mengenai pola makan apa saja yang harus dikonsumsi dan yang harus dihindari dari setiap golongan darah guna memenuhi asupan gizi yang pas.

Berdasarkan pembahasan tersebut maka penulis akan membangun Layanan Informasi Pada Rumah Sakit Mamami Kota Kupang yang diharapkan dapat membantu pihak Rumah Sakit dalam mewujudkan pelayanan terhadap pasien dan masyarakat Kota Kupang dalam mendapatkan informasi yang lebih efektif dan efisien.

\section{METODOLOGI PENELITIAN}

Pada penelitian ini penulis menggunakan metode deskriptif, yaitu metode yang menggambarkan suatu keadaan atau permasalahan yang sedang terjadi berdasarkan fakta-fakta dan data-data yang diperoleh dan dikumpulkan pada waktu melaksanakan penelitian. Pengumpulan data yang dilakukan dalam penelitian ini adalah dengan cara:

1. Studi pustaka

Dilakukan dengan kegiatan mencari literatur atau sumber pustaka pendukung penelitian yang mampu menyelesaikan penelitian dan memberikan informasi yang memadai serta membantu mempertegas teori-teori yang ada.

2. Observasi

Penulis mengadakan pengamatan langsung pada rumah sakit Mamami. Dengan cara pengumpulan data dan mengadakan pencatatan secara sistematis terhadap permasalahan yang terjadi sebagai acuan dalam penelitian ini.

3. Wawancara

Penulis melakukan kegiatan tanya jawab secara langsung kepada direktur dan petugas Rumah Sakit Mamami untuk mendapatkan informasi secara lisan dengan tujuan untuk memperoleh data yang dapat menjelaskan ataupun menjawab suatu permasalahan penelitian mengenai layanan informasi kesehatan dan tata kelolah administrasi.

\section{Alur Penelitian}

Prosedur penelitian yaitu tahapan-tahapan yang dilalui oleh peneliti dimulai dari permulaan penggumpulan data sampai kesimpulan, yang membentuk sebuah alur yang sistematis. Metodologi penelitian ini digunakan sebagai pedoman peneliti dalam pelaksanaan penelitian. Berikut ini rancangan flowchart metodologi penelitian. 


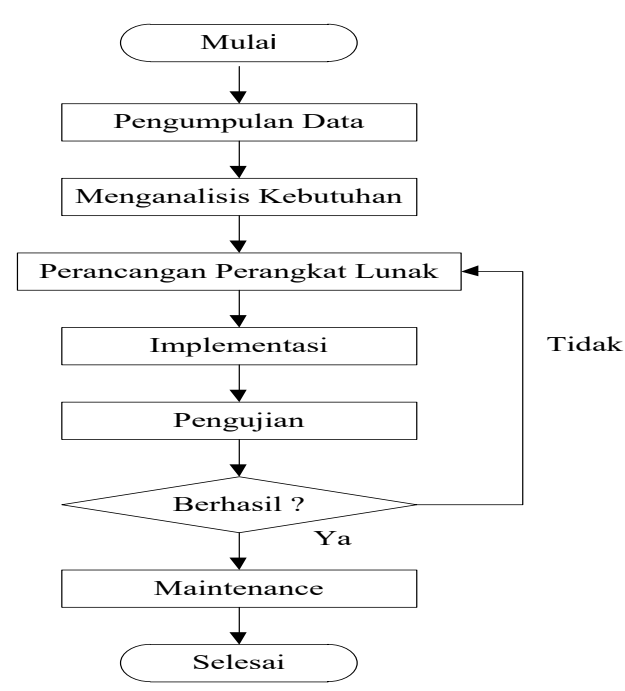

Gambar 1. Prosedur Penelitian

\section{Analisis Dan Perancangan Sistem}

Deskripsi Sistem

1. Perspektif Produk

Aplikasi Layanan Informasi Rumah Sakit Mamami Kota Kupang Berbasis Website adalah sebuah perangkat lunak yang dibuat untuk membantu pihak Rumah Sakit Mamami dalam memberikan informasi tentang pelayanan kesehatan dan masyarakat lebih mudah mendapatkan informasi.

Pengguna dari aplikasi yang dibangun $\mathrm{t}$ erdiri dari admin, bidan, dokter, fasilitas, kunjungan, laboratorium, misi, obat, pasien, perawat, poliklinik, rekam medis, sejarah, tindakan dan visi. Dimana admin bertugas menginput data bidan, datadokter, fasilitas, kunjungan, laboratorium, misi, obat, pasien, perawat, poliklinik, rekam medis, sejarah, tindakan dan visi.

1. Use case diagram
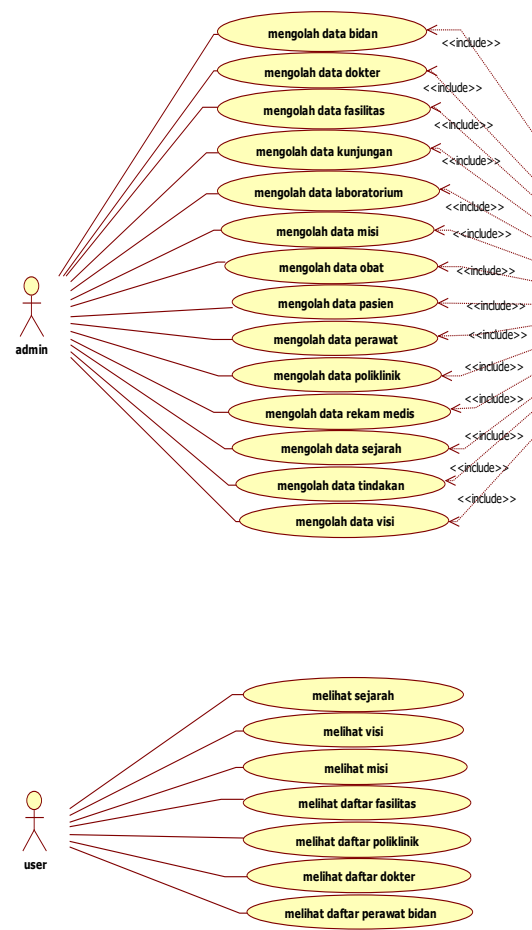

Gambar 2. Use Case Diagram

2. Class Diagram

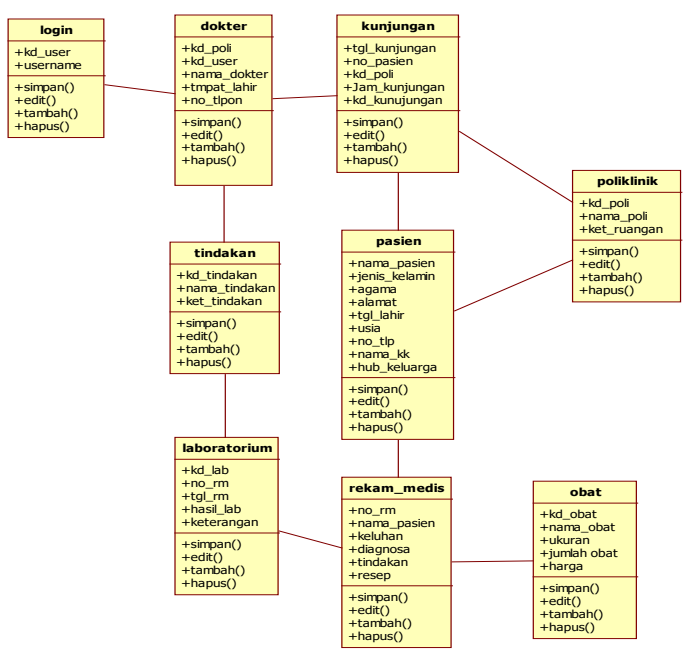

Gambar 3. Class Diagram

\section{HASIL DAN PEMBAHASAN}

a. Antarmuka form menu utama

Menu utama adalah halaman yang pertama kali muncul saat pengguna mengunjungi aplikasi tersebut. Halaman menu utama yang terdapat pada aplikasi tersebut terdiri dari beberapa menu yaitu: Home, Profil, Fasilitas, Tenaga Medis, Contact, dan Admin Area. 


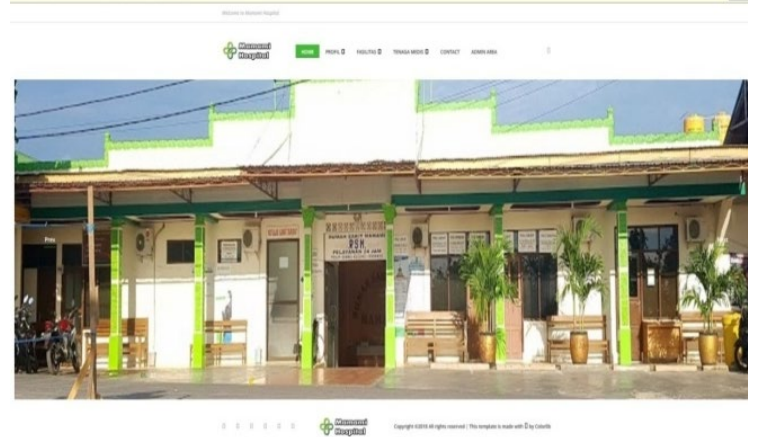

Gambar4. Antarmuka Form Menu Utama

\section{b. Antarmuka Form Login}

Form ini yang ada pada aplikasi Rumah Sakit guna memudahkan admin untuk melakukan login kedalam sistem tersebut. Berikut adalah tampilan form login :

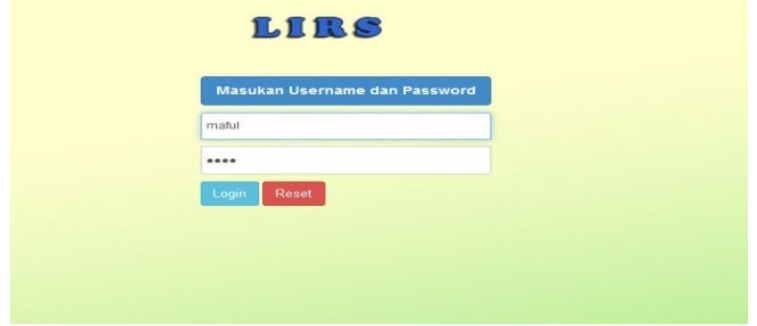

Gambar 5. Antarmuka Form Login.

c. Antarmuka Form Sejarah Rumah Sakit Mamami

Form ini yang ada pada aplikasi rumah sakit untuk dapat melihat sejarah rumah sakit. Berikut adalah tampilan antarmuka Form sejarah rumah sakit :

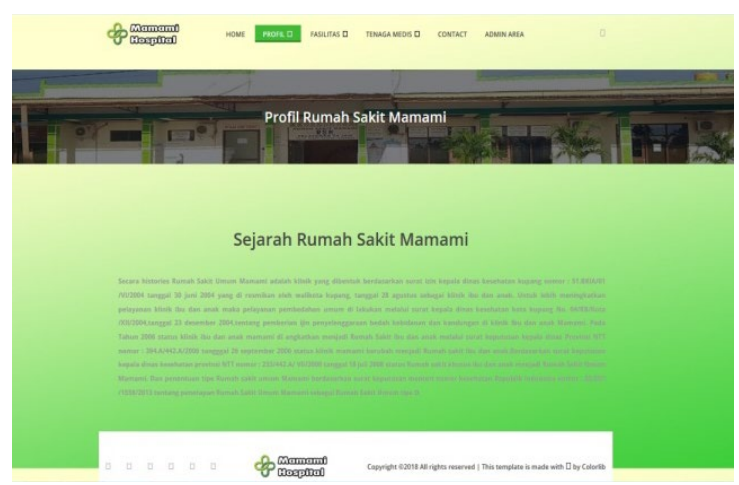

Gambar 6. Antarmuka Form Sejarah Rumah Sakit Mamami

\section{d. Antarmuka Form Fasilitas}

Form ini yang ada pada aplikasi rumah sakit untuk dapat melihat fasilitas rumah sakit. Berikut adalah tampilan antarmuka Form fasilitas rumah sakit :

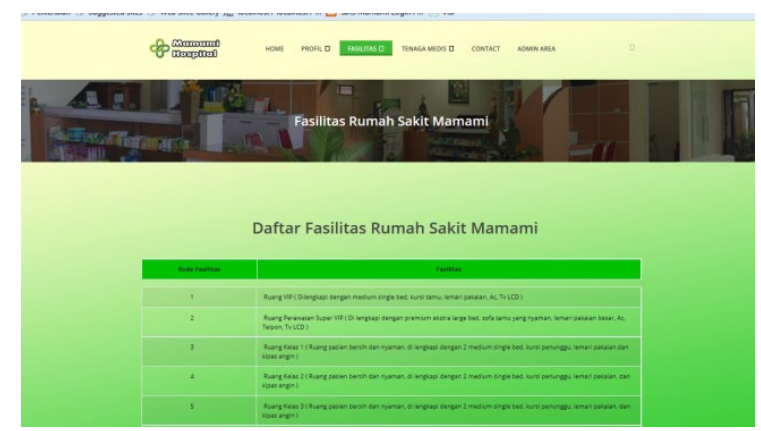

Gambar 7. Antarmuka Form Fasilitas

\section{e. Antarmuka Form Daftar Poli}

Form ini yang ada pada aplikasi rumah sakit untuk dapat melihat daftar poli rumah sakit. Berikut adalah tampilan antarmuka Form poli rumah sakit :

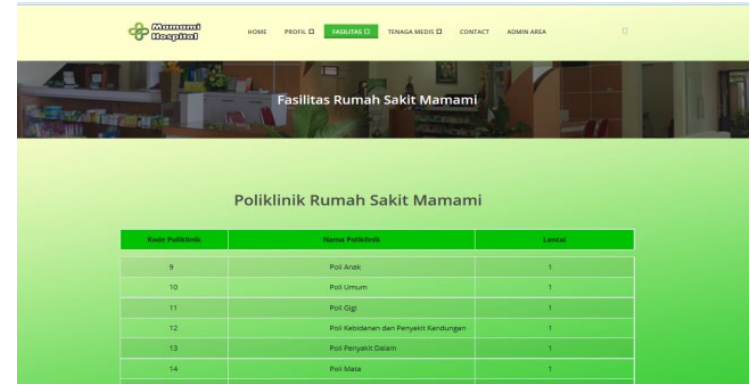

Gambar 8. Antarmuka Form Daftar Poli

f. Antarmuka Form Daftar Dokter

Form ini yang ada pada Aplikasi Rumah Sakit untuk dapat melihat daftar dokter Rumah Sakit. Berikut adalah tampilan antarmuka Form daftar dokter Rumah Sakit :

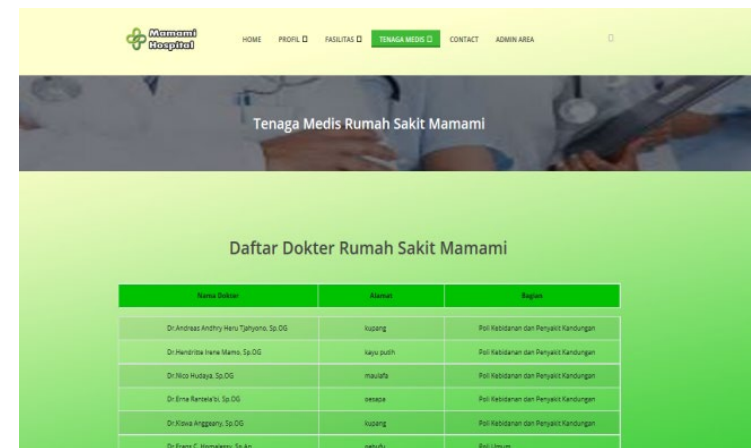

Gambar 9. Antarmuka Form Daftar Dokter

\section{g. Antarmuka Daftar Perawat}

Form ini yang ada pada Aplikasi Rumah Sakit untuk dapat melihat daftar perawat Rumah Sakit. Berikut adalah tampilan antarmuka Form daftar perawat rumah sakit : 


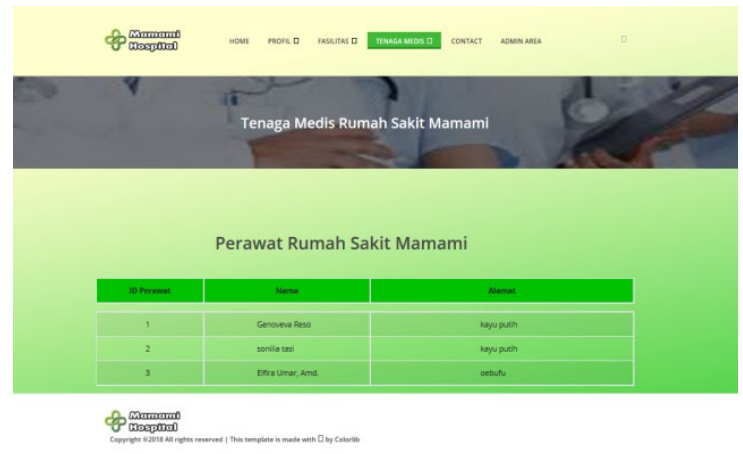

Gambar 10. Antarmuka Form Data Perawat

h. Antarmuka Form Daftar Bidan

Form ini yang ada pada Aplikasi Rumah Sakit untuk dapat melihat daftar bidan Rumah Sakit. Berikut adalah tampilan antarmuka Form daftar bidan Rumah Sakit :

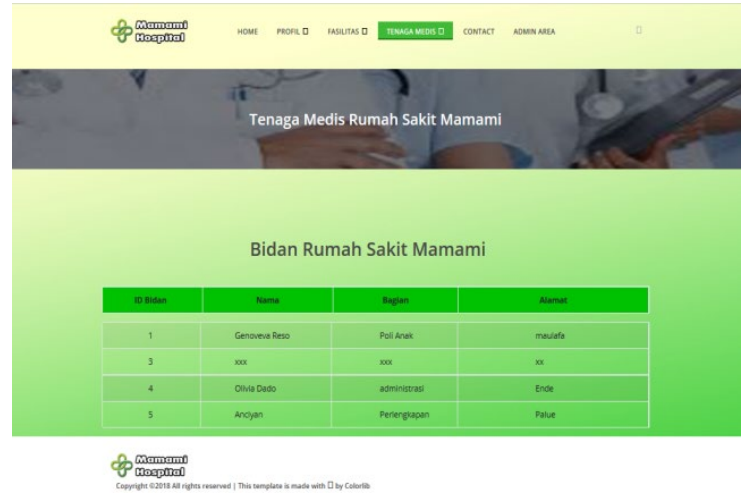

Gambar 11. Antarmuka Form Daftar Bidan

\section{i. Antarmuka Form Contact}

Form ini yang ada pada Aplikasi Rumah Sakit untuk dapat melihat contact Rumah Sakit. Berikut adalah tampilan antarmuka Form contact Rumah Sakit :

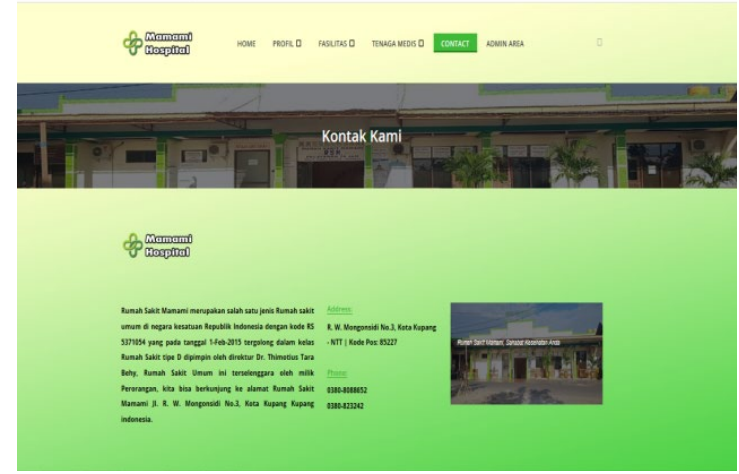

Gambar 12. Antarmuka Form Contac

\section{Pengujian Sistem}

Pengujian dibagi menjadi dua bagian yaitu pengujian fungsionalitas perangkat lunak dan pengujian unjuk kerja sistem oleh pengguna.

1. Pengujian fungsionalitas
Pengujian fungsionalitas perangkat lunak dilakukan oleh pembuat sistem untuk menguji fungsi-fungsi yang terdapat dalam sistem. Saat pengujian sistem dilakukan, penulis menggunakan perangkat keras dan perangkat lunak sebagai berukut:

a. Perangkat keras

1. Laptop dengan spesifikasi processor Intel(R) Celeron(R) CPU N2840@ $2.16 \mathrm{GHz} 2.16 \mathrm{GHz}$

2. Memory 2.0 GB RAM

3. Harddisk $500 \mathrm{~GB}$

4. Printer iP237

b. Perangkat lunak

1. Sistem Operasi Windows 7

2. Web Editor Adobe Dreamweaver

3. Xampp

\section{Analisis Kelebihan dan Kekurangan Sistem}

Setelah dilakukan pengujian fungsionalitas perangkat lunak, dan pengujian untuk kerja sistem, ditemukan beberapa kelebihan dan kekurangan dari aplikasi, diantaranya adalah sebagai berikut:

1. Kelebihan

Aplikasi ini dapat menampilkan informasi layanan kesehatan yang ada di Rumah Sakit Mamami Kota Kupang dan dapat memudahkan pengguna dalam menggunakan aplikasi yang dibangun.

2. Kekurangan

Belum adanya fitur untuk penyampaian kritik dan saran.

\section{KESIMPULAN DAN SARAN}

\section{Simpulan}

1. Aplikasi berbasis website ini dapat membantu pihak Rumah Sakit Mamami dalam memberikan informasi tentang pelayanan-pelayanan kesehatan yang ada pada Rumah Sakit Mamami.

2. Dengan adanya aplikasi ini masyarakat lebih mudah mendapatkan informasi tentang semua fasilitas yang ada pada Rumah Sakait Mamami. 


\section{DAFTAR PUSTAKA}

Adelheid, 2014. Cara Mudah Membuat Website Dan Promosi Ke SEO, Yogyakarta(ID) : Andi.

Asropudin, 2013. Dasar Pemrograman Web PHP MySql Dengan Dreamweaver, Jawa Barat (ID) : Jurnal Nasioanal JMII, Volume 2, No 1.

Insani, 2017 Mewujudkan Kota Responsif Melalui Smart City, Jurnal Ilmu, Malang(ID) : Administrasi Publik, Volume 2, No 1.

Jumiati, 2015. Layanan Informasi Bimbingan Konseling. Bandung(ID) : Eleman.

Menteri Kesehatan Republik Indonesia, 2010.

No.340/MENKES/PER/III/2010, Jakarta(ID).

Saudeli, 2014. Dreamweaver Untuk Orang Awam. Palembang(ID) : Erlangga.

Sudaryono, 2014. Perilaku Konsumen Dalam Prespektif Pemasaran Jakarta : Malang(ID) : Lentera Ilmu Cendekia, Jurnal Ilmu Administrasi Publik, Volume 2, No 1. 